\title{
GC-MS Analysis, Antimicrobial and Antioxidant Activities of Extracts of the Aerial Parts of Conyza sumatrensis
}

\section{OLAPEJU O. AIYELAAGBE ${ }^{1}$, STEPHEN O. OGUNTOYE ${ }^{2}$, ABDULMUMEEN A. HAMID ${ }^{2 *}$, ADEBOLA M. OGUNDARE ${ }^{3}$, DAVID B. OJO ${ }^{3}$, AJIBOLA AJAO ${ }^{2}$, NURUDEEN O. OWOLABI ${ }^{2}$}

\author{
Department of Chemistry, University of Ibadan, Ilorin, Nigeria \\ Department of Chemistry, University of Ilorin, Ilorin, Nigeria \\ Department of Industrial Chemistry, University of Ilorin, Ilorin, Nigeria \\ *Corresponding Author: Tel No: +2347035931646 \\ E-mail: hamidmemo@gmail.com, hamid.aa@unilorin.edu.ng
}

\begin{abstract}
:
Phytochemical analyses as well as antimicrobial and antioxidant activities of the extracts of $C$. sumatrensis aerial parts were investigated in this study. METHODS: The aerial parts of $C$. sumatrensis were air dried, weighed and exhaustively extracted with hexane, ethyl acetate and methanol successively. The crude extracts were screened for metabolites. These extracts of the plant were evaluated for antimicrobial and antioxidant activities using agar diffusion and DPPH method respectively. The extracts were also analysed using Gas chromatography Mass spectrometry, and the chromatogram coupled with mass spectra of the compounds were matched with a standard library. RESULTS: Preliminary phytochemical investigation of crude n-hexane, ethyl acetate and methanol extracts of the aerial parts of Conyza sumatrensis revealed the presence of anthraquinones, flavonoids, terpenoids, phenolics, tannin, glycosides and carbohydrate. All the crude extracts gave a clear zone of inhibition against the growth of the test bacteria (Staphylococcus aureus, Escherichia coli, Bacillus subtilis, Pseudomona aeruginosa, Salmonella typhi, Klebsiellae pneumonae) at moderate to high concentrations, as well as test fungi (Candida albicans, Aspergillus niger, penicillium notatum and Rhizopus stolonifer) at high concentration. Methanolic extract exhibited significant radical scavenging property with $\mathrm{IC}_{50}$ of $17.08 \mu \mathrm{g} / \mathrm{mL}$ while n-hexane and ethyl acetate extracts showed no significant antioxidant activity. GC-MS of N-hexane extract showed a total number of eleven chemical constituents with $\alpha$-Farnesene and spathulenol being the most abundance compounds constituting 20.27 and $22.28 \%$ of the extract respectively. Ethyl acetate extract revealed thirteen compounds with two most abundant compounds, cis- $\beta$-farnesene $(16.64 \%)$ and cis-pinane $(21.09 \%)$. While methanolic extract affords seventeen compounds with Ephytol being the most abundant compound (19.36\%). (C) JASEM
\end{abstract}

http://dx.doi.org/10.4314/jasem.v20i1.13

KEYWORDS: Antimicrobial activity, Antioxidant, GC-MS analysis, Phytochemicals, Conyza sumatrensis

\section{Introduction}

The World Health Organization estimates that approximately 80 percent of the world's population relies primarily on traditional medicines as sources for their primary health care (Fansworth et al., 1985). Over 100 chemical substances that are considered to be important drugs that are either currently in use or have been widely used in one or more countries in the world have been derived from several natural plants. Approximately 75 percent of these substances were discovered as a direct result of chemical studies focused on the isolation of active substances from plants used in traditional medicine (Cragg and Newman, 2001).

Medicinal plants are plants which contain in one of its organs substances that can be used for therapeutic or which are precursors for the synthesis of useful drugs. Medicinal plants are the richest bio-resource of drugs of traditional systems of medicine, modern medicines, nutraceuticals, food supplements, folk medicines, pharmaceutical intermediates and chemical entities for synthetic drugs (Ncube et al., 2008). Conyza sumatrensis commonly called broadleaf fleabane is a dicotyledonous herb of the family of asteraceae widely occurring in Nigeria especially in the Niger Delta region and also in central Kenya. It is an erect, hairy, annual herb up to $120 \mathrm{~cm}$ high with sessile and deeply serrated leaves, the stem is covered with two types of hairs: short hairs directed upward and long hairs patent with upward direction. Leaves are numerous, simple and alternate (Opiyo et al., 2010). Traditionally, the plant has been used across West Africa to treat ailments like chickenpox, smallpox, sore throat, ringworm and other skin related diseases, toothache and to stop bleeding from injuries (Ogbeche et al., 1997). The extract of the leaf of $C$. sumatrensis is used in the treatment of pulmonary problems. The plant is used in treating eye problems and its sap is effective in 
treating paralysis, epilepsy and convulsion. It can be used in arresting fever. Leaves are used in the treatment of tuberculosis and asthma (Burkill, 1985). These phytochemicals and biological activity studies of $C$. sumatrensis are to establish the scientific facts in order to justify the forklore uses of the plant.

\section{MATERIALS AND METHODS}

Sample Preparation: The plant was collected from Amurin, Ondo state, Nigeria in the month of November, 2014. The plant was identified and authenticated by the plant taxonomist, Mr. Bolu Ajayi of the Department of Plant Biology, University of Ilorin where a voucher specimen (UIH002/1145) was deposited in the herbarium. The plant was extracted using standard procedure according to Das et al., 2010. The aerial parts of $C$. sumatrensis were air dried and crushed into smaller pieces using mortar and pestle. The plant was weighed and extracted using serial exhaustive extraction method by moving from a non-polar (hexane) solvent to a medium polar solvent (ethyl acetate) and then to a polar solvent (methanol).

Phytochemical screening: Preliminary phytochemical screening of the crude extract was carried out using the modified methods described by Pranshant, et al., 2011.

\section{Antimicrobial assay: \\ Organisms: Cultures of six human pathogenic bacteria made up of four gram negative and two gram positive were used for the antibacterial assay. These include: Salmonella typhii, Escherichia coli, Pseudomonas aeruginosa and Klebsiellae pneumonae which are gram-negative, while Bacillus subtilis and Staphylococcus aureus are gram-positive bacteria. Four fungi were also utilized for the Antifungal assay. These are: Candida albicans, Aspergillus niger, Rhizopus stolon and Penicillum notatum. All the microorganisms used were clinical strains from the Medical Microbiology Department, University College Hospital, Ibadan, screened in the Laboratory of Pharmaceutical Microbiology Department, University of Ibadan.}

Media used: Nutrient agar, Sabouraud dextrose agar, nutrient broth and tryptone soya agar were used in this study. N-hexane, ethyl acetate and methanol were also used in solubilizing the extracts and as negative controls in the assays.

Antimicrobial agents used: Gentamycin $(10 \mu \mathrm{g} / \mathrm{mL})$ and Tioconazole $(0.7 \mathrm{mg} / \mathrm{mL})$ were employed as standard reference drugs in the study

\section{Determination of Antimicrobial activity}

Agar diffusion-Ditch method (bacteria): An overnight culture of each organism was prepared by taken two wire-loop of the organism from the stock, each inoculated into $5 \mathrm{ml}$ of sterile nutrient broth and incubated for $24 \mathrm{hr}$ at $37^{\circ} \mathrm{C}$. $0.1 \mathrm{~mL}$ of each organism was taken from the overnight culture and put into the $9.9 \mathrm{~mL}$ of sterile distilled water to obtained $10^{-2}$ inoculum concentration of the test organism. $0.2 \mathrm{~mL}$ was taken from the diluted test organism $\left(10^{-2}\right)$ into the prepared sterile nutrient agar cooled to about $45^{\circ} \mathrm{C}$, then poured into sterile petri dishes and allowed to solidify for about $60 \mathrm{~min}$. A sterile corkborer of $8 \mathrm{~mm}$ diameter was used to make 8 wells on the media according to the number of the diluted extracts for the experiment. The graded concentrations $(6.25-200 \mathrm{mg} / \mathrm{mL})$ of the extracts were put into each well and separated from the controls. The studies were done in duplicates to ascertain the results obtained. The plates were left on the bench for about $2 \mathrm{hr}$ to allow the extract diffuse properly into the nutrient agar i.e. pre-diffusion. The plates were incubated for $24 \mathrm{hr}$ at $37^{\circ} \mathrm{C}$.

Agar diffusion-Surface method (fungi): A sterile sabouraud dextrose agar was prepared accordingly and aseptically poured into the sterile plates in triplicates and solidified properly. $0.2 \mathrm{~mL}$ of the $10^{-2}$ inoculum concentration of the test organism was spread on the surface of the agar using a sterile Petridish to cover all the surface of the agar. Eight wells were bored by using a sterile cork-borer of $8 \mathrm{~mm}$ diameter. The graded concentrations of the extracts were put into each well separately with the controls. All the plates were left on the bench for $2 \mathrm{hr}$ to allow the extract diffuse properly into the agar i.e. prediffusion. The plates were incubated at $25^{\circ} \mathrm{C}$ for $72 \mathrm{hr}$

Antioxidant Activity: The ability of the samples to scavenge DPPH free radicals was assessed by the standard method adopted with suitable modifications (Sies, 1997). The stock solutions of extracts were prepared in methanol to achieve the concentration of $1 \mathrm{mg} / \mathrm{mL}$. Dilutions were made to obtain concentrations of $1000,500,250,125,62.5,31.25$, 15.62, 7.81, 3.90 and $1.99 \mu \mathrm{g} / \mathrm{mL}$. DPPH $(2,2-$ diphenyl-1-hydrazine) is widely used to test the ability of compounds to act as free radical scavengers or hydrogen donors, and to evaluate antioxidant activity. The absorbance was measured in triplicate at varying concentrations and the mean absorbance was determined. Parallel to examination of the antioxidant activity of plant extracts, the value for the standard compound (Ascorbic acid) was obtained (Table 3.16) and compared to the values of the antioxidant activity, the percentage inhibitions of the serial concentrations of the methanolic DPPH extracts and that of the standard which was determined at different concentrations using the expression as shown below.

$$
\% \text { inhibition }=\left(\frac{\text { A of control }- \text { Aof sample }}{\text { Aof control }}\right)
$$

The $\mathrm{IC}_{50}$ values (Inhibition Concentration at 50\%) were estimated from the \% inhibition versus 
concentration plot, using a non-linear regression algorithm.

GC-MS analysis of the extracts: GC-MS was performed with Agilent 19091GC plus automatic sampler system coupled with a quadruple mass spectrometer 433HP-5MS. Compounds were separated in HP5MS column fused with phenyl methyl silox, ( length; $30 \mathrm{~m}$ x $250 \mu \mathrm{m}$; film thickness $0.25 \mu \mathrm{m})$. Samples were injected at a temperature of about $250^{\circ} \mathrm{C}$ with a split ratio of $10: 1$ with a flow rate of helium $1 \mathrm{~mL} / \mathrm{min}$. Extracts of the aerial parts of $C$ summatrensis were dissolved in the respective solvent (n-hexane, ethyl acetate and methanol) to form solution. After this, the extracts were inserted into GC-MS instruments for chromatographic separation of chromatograms and mass spectra.

\section{RESULTS AND DISCUSSION}

The preliminary phytochchemical screening of the crude extracts of $C$. sumatrensis revealed the presence of bioactive compounds such as phenolics, tannins, saponin, anthraquinone, steroids, glycosides and carbohydrate as shown in table 1 . The presence of these bioactive compounds is an indication that this plant may contain pharmacological activities

The antimicrobial activity was determined using the Agar diffusion - ditch plate method for the bacteria and the surface plate method for the fungi with $8 \mathrm{~mm}$ well diameter. The activity of the extracts was measured as clear zone of inhibition of the microbial growth that surrounds each well. The extracts exhibit significant antimicrobial activity against some of the test organisms at a concentration of $200 \mathrm{mg} / \mathrm{mL}$.

Table 1: Phytochemical Screening of hexane, ethyl acetate and methanol extracts of

\begin{tabular}{lccc}
\multicolumn{4}{c}{ C. sumatrensis } \\
\hline Chemical constituents & Hexane extract & $\begin{array}{l}\text { Ethyl acetate } \\
\text { extract }\end{array}$ & $\begin{array}{l}\text { Methanol } \\
\text { extract }\end{array}$ \\
\hline Alkaloids & & - & - \\
Anthraquinones & - & + & + \\
Glycosides & - & - & + \\
Steroids & - & + & + \\
Phenolics & + & - & + \\
Flavonoids & - & + & + \\
Tannins & - & - & + \\
Saponins & - & + & + \\
Carbohydrates & - & - & + \\
Terpenoids & - & + & + \\
\hline
\end{tabular}

Table 2: Antimicrobial activity of hexane extract of $C$. sumatrensis

\begin{tabular}{lcccccccc}
\hline Microorganisms & \multicolumn{8}{c}{ Mean zone of inhibition $(\mathbf{m m})$} \\
\hline S. aureus & 26 & 24 & 22 & 18 & 14 & 12 & - & 40 \\
E. coli & 24 & 22 & 18 & 16 & 14 & 10 & - & 38 \\
B. subtilis & 24 & 20 & 18 & 14 & 12 & 10 & - & 38 \\
$P$. aeruginosa & 20 & 18 & 14 & 12 & 10 & - & - & 38 \\
K. pneumonae & 16 & 14 & 12 & 10 & - & - & - & 40 \\
S. typhi & 18 & 16 & 14 & 12 & 10 & - & - & 38 \\
C. ablicans & 20 & 18 & 16 & 12 & 10 & - & - & 28 \\
A. Niger & 16 & 14 & 12 & 10 & - & - & - & 28 \\
$P$. notatum & 18 & 14 & 12 & 10 & - & - & - & 28 \\
R. stolonifer & 16 & 14 & 12 & 10 & - & - & - & 26 \\
Conc. of extracts & 200 & 100 & 50 & 25 & 12.5 & 6.25 & $-\mathrm{ve}$ & $+\mathrm{ve}$
\end{tabular}

Key: +ve = Gentamycin $10 \mu \mathrm{g} / \mathrm{ml}$ (for bacteria), Tioconazole (for fungi); -ve = Solvent of dilution

The antimicrobial assay of the $n$-hexane, ethyl acetate and methanol extract of the plant gave different mean diameter of inhibition on the six different strains of bacteria and four strains of fungi tested at concentrations ranging from $6.25-200 \mathrm{mg} / \mathrm{mL}$. Nhexane extract inhibited the growth of the test organisms at moderate to high concentration. The extract inhibits Staphylococcus aureus, Escherichia coli, Bacillus subtilis fairly at a low concentration of $6.25 \mathrm{mg} / \mathrm{mL}$, while the sensitivity of the extract was low to all test fungi [Table 2]. The activity of the nhexane extract against microorganism may be attributed to the presence of bioactive compounds such as terpenoids and steroids i.e. Table 1 which have been reported to exhibit antimicrobial activity.
Ethyl acetate extract of the aerial parts of Conyza sumatrensis inhibited the growth of all the test bacteria from range of different concentrations used (200 - 100mg/mL), and a fungus, Candida albicans at range of concentrations from $200-50 \mathrm{mg} / \mathrm{mL}$. The extract inhibits Staphylococcus aureus, Escherichia coli, Bacillus subtilis, Pseudomona aeruginosa, Salmonella typhi, Klebsiellae pneumonae and Candida albicans at high range of concentrations from 200-100mg/mL. However, three fungi (Aspergillus niger, Penicillium notatum and Rhizopus stolonifer) showed resistance to the ethyl acetate extract of the aerial parts of Conyza sumatrensis and at lower concentration of 12.5 and $6.25 \mathrm{mg} / \mathrm{mL}$ all the 
test organisms shows resistance to the crude ethyl acetate extract [Table 3].

Methanol extract of the aerial parts of Conyza sumatrensis inhibited the growth of all the test bacteria at range of concentration from $200-$ $25 \mathrm{mg} / \mathrm{mL}$, and three fungi at range of concentration from $200-100 \mathrm{mg} / \mathrm{mL}$. The methanol extract inhibits Staphylococcus aureus, Escherichia coli, Bacillus subtilis, Pseudomona aeruginosa, Salmonella typhi, Klebsiellae pneumonae, Candida albicans, Aspergillus niger and penicillium notatum at concentrations of $50-200 \mathrm{mg} / \mathrm{mL}$. However, Rhizopus stolonifer exhibits resistance at all concentrations to the methanolic extract of Conyza sumatrensis. At lower concentrations of 12.5 and $6.25 \mathrm{mg} / \mathrm{ml}$ all the test organism exhibits resistance to the crude methanolic extract as shown in Table 4. The artificial culture medium used for the antimicrobial assay showed that the methanol and ethyl acetate extracts of Conyza sumatrensis exhibit antimicrobial activity. However, when the ethyl acetate extract was tested on fungi, it only inhibits the growth of Candida albicans. While the methanolic extract has moderate effect on three fungi namely; Candida albicans, Aspergilus niger and penicillium notatum at high concentrations.

This inhibition gives credence to the fact that aerial parts of Conyza sumatrensis exhibit antibacterial and antifungal activities and hence can be used for the treatment of various illnesses due to bacteria and fungi.

Table 3: Antimicrobial activity of ethyl acetate extract of $C$. sumatrensis

\begin{tabular}{|c|c|c|c|c|c|c|c|c|}
\hline Microorganisms & & & Me & zone & inhil & on $(m$ & & \\
\hline S. aureus & 18 & 14 & 12 & 12 & 10 & - & - & 40 \\
\hline E. coli & 16 & 14 & 12 & 10 & - & - & - & 38 \\
\hline B. subtilis & 14 & 12 & 10 & - & - & - & - & 38 \\
\hline P. aeruginosa & 14 & 10 & - & - & - & - & - & 38 \\
\hline K. pneumonae & 12 & 10 & - & - & - & - & - & 38 \\
\hline S. typhi & 14 & 12 & 10 & - & - & - & - & 40 \\
\hline C. ablicans & 16 & 12 & 10 & - & - & - & - & 28 \\
\hline A. Niger & - & - & - & - & - & - & - & 28 \\
\hline P. notatum & - & - & - & - & - & - & - & 28 \\
\hline R. stolonifer & - & - & - & - & - & - & - & 26 \\
\hline $\begin{array}{l}\text { Conc. of extracts } \\
(\mathbf{m g} / \mathbf{m L})\end{array}$ & 200 & 100 & 50 & 25 & 12.5 & 6.25 & $-v e$ & $+v e$ \\
\hline
\end{tabular}

Key: + ve $=\overline{\text { Gentamycin } 10 \mu \mathrm{g} / \mathrm{ml} \text { (for bacteria), Tioconazole (for fungi); }-\mathrm{ve}=\text { Solvent }}$ of dilution

Table 4: Antimicrobial activity of methanol extract of $C$. sumatrensis Microorganisms

\begin{tabular}{|c|c|c|c|c|c|c|c|c|}
\hline \multirow{2}{*}{ S. aureus } & \multicolumn{8}{|c|}{ Mean zone of inhibition (mm) } \\
\hline & 20 & 18 & 14 & 10 & - & - & - & 40 \\
\hline E. coli & 18 & 16 & 14 & 12 & 10 & - & - & 38 \\
\hline B. subtilis & 16 & 14 & 12 & 10 & - & - & - & 38 \\
\hline P. aeruginosa & 16 & 14 & 12 & 10 & - & - & - & 38 \\
\hline K. pneumonae & 18 & 14 & 12 & 10 & - & - & - & 38 \\
\hline S. typhi & 16 & 14 & 12 & 10 & - & - & - & 40 \\
\hline C. ablicans & 16 & 14 & 12 & 10 & - & - & - & 28 \\
\hline A. Niger & 14 & 12 & 10 & - & - & - & - & 28 \\
\hline P. notatum & 12 & 10 & - & - & - & - & - & 28 \\
\hline R. stolonifer & 16 & 14 & 12 & 10 & - & - & - & 26 \\
\hline Conc. of extracts & 200 & 100 & 50 & 25 & 12.5 & 6.25 & $-v e$ & $+v e$ \\
\hline
\end{tabular}

Key: + ve = Gentamycin $10 \mu \mathrm{g} / \mathrm{ml}$ (for bacteria), Tioconazole (for fungi); -ve = Solvent of dilution

Antioxidant activity of n-hexane, ethyl acetate and methanol extracts of the aerial parts of $C$. sumatrensis and that of standard control, Ascorbic acid were shown in Table $5-9$. Methanol extract of the plant revealed high free radical scavenging activity with $\mathrm{IC}_{50}$ of $17.08 \mu \mathrm{g} / \mathrm{mL}$. N-hexane and ethyl acetate extracts of the aerial parts of $C$. sumatrensis showed low antioxidant activity (Figure 1). The percentage of inhibition of DPPH radicals by the extracts were compared with that of control, ascorbic acid [Table 5 \& 6]. 
Table 5. Absorbance and Percentage Inhibition of Ascorbic Acid Standard for DPPH Absorbance for control is 1.265

\begin{tabular}{cccccc}
\hline Conc $(\boldsymbol{\mu g} / \mathbf{m L})$ & $\mathbf{A 1}$ & $\mathbf{A 2}$ & $\mathbf{A 3}$ & $\mathbf{A V} \pm$ SD & \%I of A \\
\hline $\mathbf{1 0 0 0}$ & 0.138 & 0.138 & 0.140 & $0.139 \pm 0.0012$ & 89.02 \\
$\mathbf{5 0 0}$ & 0.150 & 0.150 & 0.150 & $0.15 \pm 0.000$ & 88.14 \\
$\mathbf{2 5 0}$ & 0.161 & 0.162 & 0.160 & $0.161 \pm 0.001$ & 87.26 \\
$\mathbf{1 2 5}$ & 0.180 & 0.180 & 0.180 & $0.180 \pm 0.000$ & 85.79 \\
$\mathbf{6 2 . 5}$ & 0.193 & 0.195 & 0.194 & $0.194 \pm 0.001$ & 84.26 \\
$\mathbf{3 1 . 2 5}$ & 0.245 & 0.245 & 0.245 & $0.245 \pm 0.000$ & 80.67 \\
$\mathbf{1 5 . 6 2}$ & 0.311 & 0.311 & 0.311 & $0.311 \pm 0.000$ & 75.440 \\
$\mathbf{7 . 8 1}$ & 0.453 & 0.452 & 0.454 & $0.453 \pm 0.001$ & 64.18 \\
$\mathbf{3 . 9}$ & 0.782 & 0.781 & 0.78 & $0.781 \pm 0.001$ & 38.26 \\
$\mathbf{1 . 9 5}$ & 0.991 & 0.991 & 0.991 & $0.991 \pm 0.000$ & 21.66 \\
\hline
\end{tabular}

Table 6: DPPH Antioxidant activity and \%inhibition of Aerial Parts Extracts of C. sumatrensis and 0.566, 0.566 and 0.518 as absorbance for control

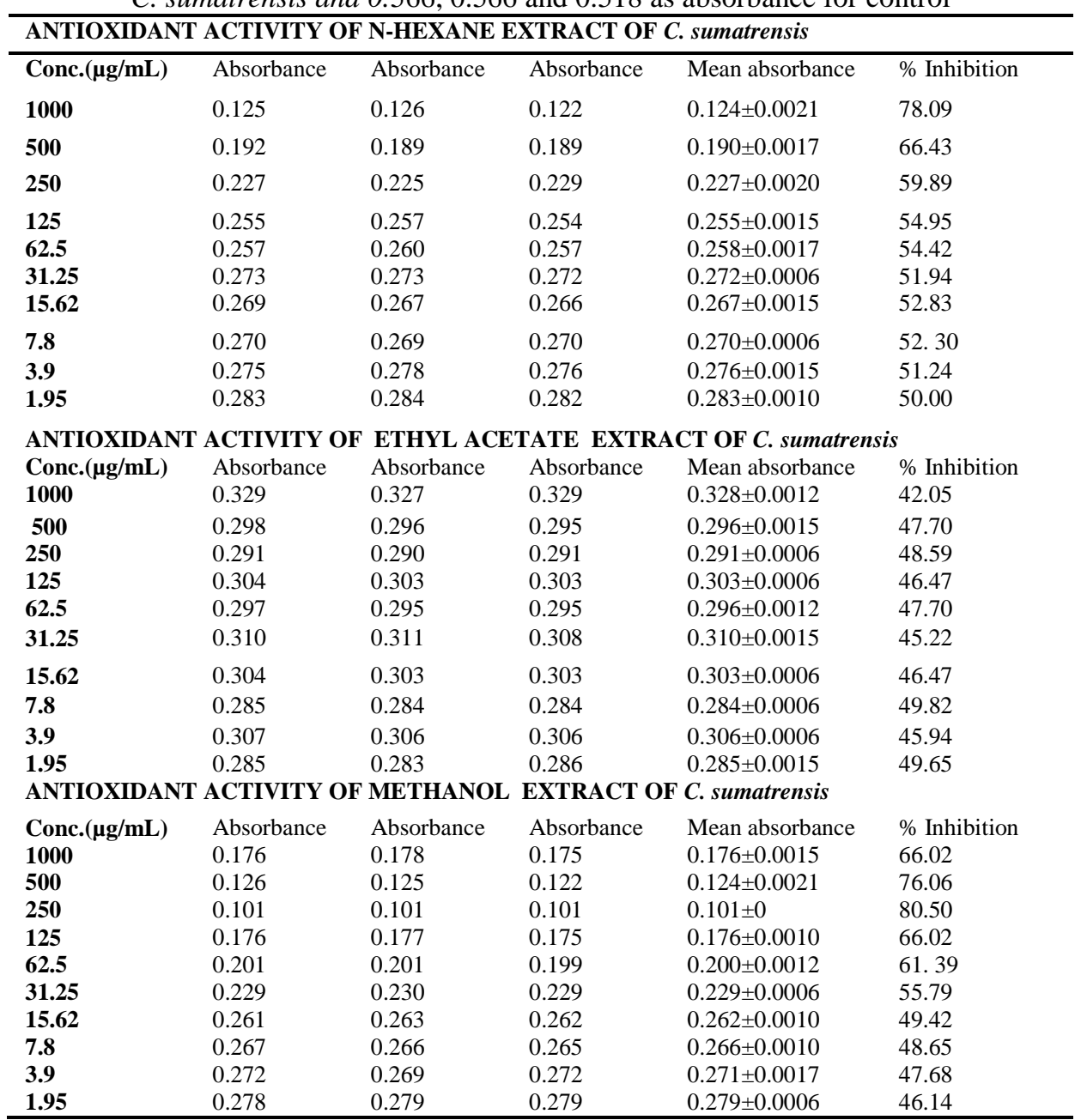




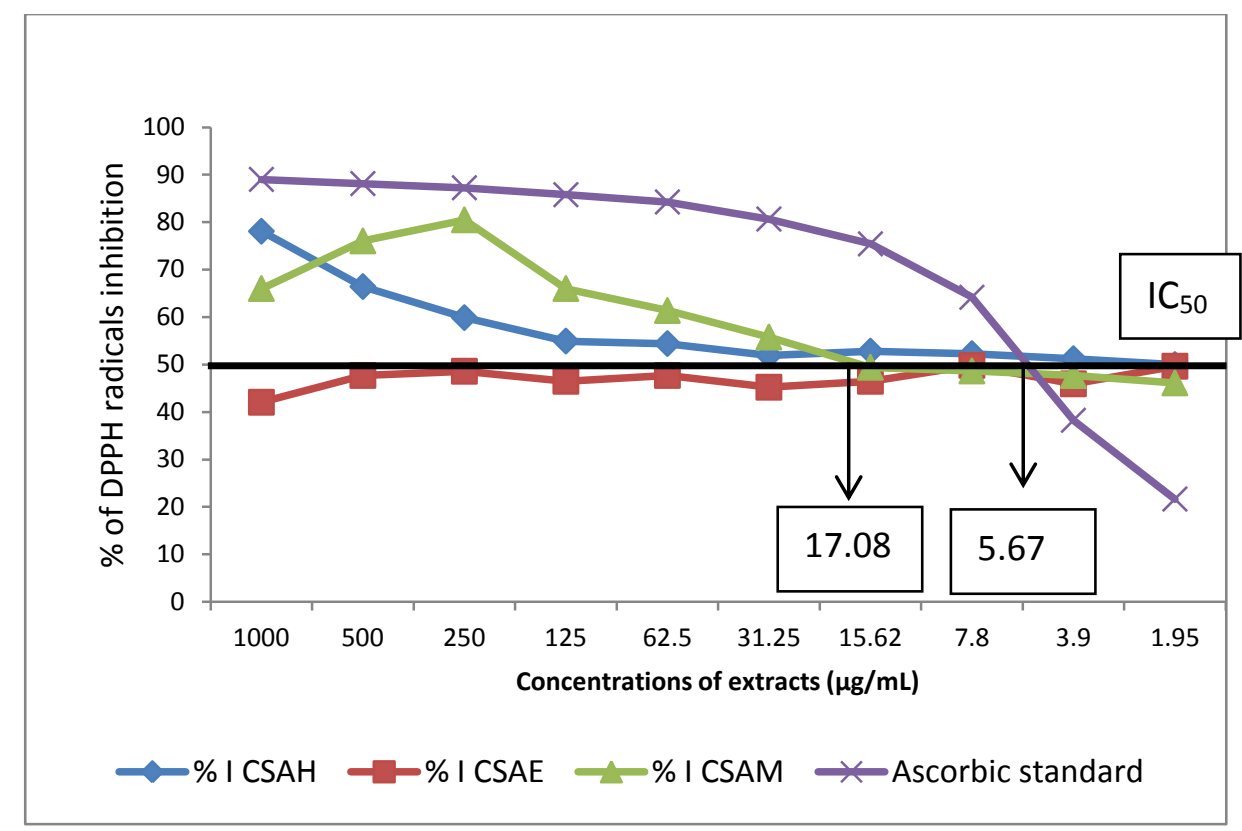

Fig 1: \% of DPPH radical inhibition versus concentration $(\mathrm{mg} / \mathrm{mL})$ for determination of Antioxidant Activity of the aerial parts extracts of C. Sumatrensis

KEY: $\quad$ SD = Standard deviation; $\quad \% \mathbf{I}=$ Percentage inhibition; CSA = Conyza sumatrensis aerial parts; CSAH - N-hexane extract of Conyza sumatrensis aerial parts; CSAE - Ethyl acetate extract of Conyza sumatrensis aerial parts; CSAM - Methanol extract of Conyza sumatrensis aerial parts

GC-MS analysis results revealed that n-hexane extract showed the presence of 11 vertical peaks, the comparison of the peaks with pherobase library indicated the presence of eleven compounds as showed in Table 7. $\alpha$-Farnesene and spathulenol are the most abundant (20.27\%), (22.276\%), molecular formula of $\mathrm{C}_{15} \mathrm{H}_{24}, \mathrm{C}_{15} \mathrm{H}_{24} \mathrm{O}$, retention time 14.082, 17.866 respectively. The fragment ions 133, 105 confirm the molecular mass of $\alpha$-farnesene (204).

GC-MS result of ethyl acetate extract revealed seventeen compounds and these compounds were compared with standard library (pherobase). These compounds are $\gamma$-seliene $(0.64 \%)$, caryophyllene $(9.20 \%), \alpha$-trans-bergemotene (5.06), cis- $\beta$-farnesene $(16.64 \%), \quad \gamma$-muurolene $(1.03 \%), \quad \alpha$-curcumene $(2.29 \%), \delta$-cadiene $(2.12 \%)$, trans nerolidol $(1.52 \%)$, Cis-pinane $(21.09 \%)$, 1,4- eicosadiene $(2.93 \%)$, Ephytol $(9.01 \%)$, phytol acetate $(7.26 \%)$ [Table 6].

The fragments ions 82, 95 and 123 of most abundant compound in ethyl acetate extract, cis-pinane (\% abundance, 21.09) correspond to molecular formula $\mathrm{C}_{6} \mathrm{H}_{10},-\mathrm{C}_{7} \mathrm{H}_{11}$ and $-\mathrm{C}_{9} \mathrm{H}_{15}$, while cis- $\beta$-farnesene $(\%$ abundance, 16.64), which revealed fragment ions
120,133 and 161 correspond to molecular formula $\mathrm{C}_{6} \mathrm{H}_{9},-\mathrm{C}_{10} \mathrm{H}_{13},-\mathrm{C}_{12} \mathrm{H}_{17}$ [Table 8].

The result of the GC-MS of the methanol extract of the plant revealed twenty peaks indicating that a mixture of twenty compounds were present in the extract. Comparison of the peaks with a standard library confirms the presence of Coumaran (0.63\%), $1,4 \quad$ dihydroxybenzene $(1.99 \%)$, 2methoxylvinylphenol (7.96\%), 2,6-dimethoxylphenol $(0.92 \%)$, Eugenol $(8.51 \%)$, Caryophyllene $(3.99 \%)$, $\alpha$-farnesene $(1.55 \%)$, Cis- $\beta$-farnesene $(6.72 \%)$, 4-epicubedol (1.18\%), Nerolidyl acetate (0.87\%), Spathulenol (11.02\%), Cis- pinane (1.00\%), Methyl palmitate $(13.67 \%)$, methyl linoleate $(1.91 \%)$, Methyl linolenate $(11.69 \%)$, E-phytol $(19.36 \%)$ as shown in table 7. The most abundant constituent, E-phytol (\% abundance, 19.36) revealed the following fragment ions of the molecular formular $-\mathrm{C}_{3} \mathrm{H}_{3} \mathrm{O}(55 \mathrm{~g} / \mathrm{mol})$, $\mathrm{C}_{4} \mathrm{H}_{7} \mathrm{O}(71 \mathrm{~g} / \mathrm{mol})$ and $-\mathrm{C}_{8} \mathrm{H}_{10} \mathrm{O}(123 \mathrm{~g} / \mathrm{mol})$. Another major constituent of the extract, methyl palmitate $(\%$ abundance, 13.67) showed the following fragments of its molecular formular $-\mathrm{C}_{3} \mathrm{H}_{6} \mathrm{O}_{2}(74 \mathrm{~g} / \mathrm{mol})$, $\mathrm{C}_{4} \mathrm{H}_{7} \mathrm{O}_{2} \quad(87 \quad \mathrm{~g} / \mathrm{mol}), \quad-\mathrm{C}_{10} \mathrm{H}_{23} \quad(143 \quad \mathrm{~g} / \mathrm{mol})$ [Table9]. 
Table 7: GC-MS Analysis of N-hexane Extract of the Aerial Parts of Conyza sumatrensis

\begin{tabular}{llllll}
\hline SN & Compound name & Formula & Peak area \% & $\begin{array}{l}\text { Molecular } \\
\text { Weight }(\mathbf{g} / \mathbf{m o l})\end{array}$ & $\begin{array}{l}\text { Retention } \\
(\text { min) }\end{array}$ \\
\hline $\mathbf{1}$ & Caryophyllene & $\mathrm{C}_{15} \mathrm{H}_{24}$ & 8.94 & 204 & 13.025 \\
$\mathbf{2}$ & a-Bergamotene & $\mathrm{C}_{15} \mathrm{H}_{24}$ & 4.30 & 204 & 13.450 \\
$\mathbf{3}$ & $\beta$-Farnesene & $\mathrm{C}_{15} \mathrm{H}_{24}$ & 20.27 & 204 & 14.082 \\
$\mathbf{4}$ & $\beta$-Cubebene & $\mathrm{C}_{15} \mathrm{H}_{24}$ & 5.04 & 204 & 14.882 \\
$\mathbf{5}$ & $\alpha$-Bisabolol & $\mathrm{C}_{15} \mathrm{H}_{26} \mathrm{O}$ & 1.97 & 222 & 17.341 \\
$\mathbf{6}$ & Spathulenol & $\mathrm{C}_{15} \mathrm{H}_{24} \mathrm{O}$ & 22.28 & 220 & 17.886 \\
$\mathbf{7}$ & Tricyclo-undecan-3-ol- & $\mathrm{C}_{15} \mathrm{H}_{24} \mathrm{O}$ & 2.09 & 220 & 20.881 \\
& trimethyl & & & & \\
$\mathbf{8}$ & 3,7,11,15-tetramethyl-2- & $\mathrm{C}_{20} \mathrm{H}_{22} \mathrm{O}$ & 19.10 & 278 & 24.716 \\
& hexadecen-1-ol & & & & 26.924 \\
$\mathbf{9}$ & Methyl Palmitate & $\mathrm{C}_{16} \mathrm{H}_{46} \mathrm{O}_{2}$ & 1.76 & 270 & 28.275 \\
$\mathbf{1 0}$ & Palmitic acid & $\mathrm{C}_{16} \mathrm{H}_{32} \mathrm{O}_{2}$ & 5.88 & 256 & 31.378 \\
$\mathbf{1 1}$ & Phytol & $\mathrm{C}_{20} \mathrm{H}_{38} \mathrm{O}$ & 8.01 & 294 & \\
\hline
\end{tabular}

Table 8: GC-MS Analysis of Ethyl acetate Extract of the Aerial Parts of Conyza sumatrensis

\begin{tabular}{|c|c|c|c|c|c|}
\hline $\mathbf{S} / \mathbf{N}$ & Compound name & Peak area \% & $\begin{array}{l}\text { Molecular } \\
\text { formula }\end{array}$ & $\begin{array}{l}\text { MW } \\
\text { g/mole }\end{array}$ & $\begin{array}{l}\begin{array}{l}\text { Retention time } \\
(\text { min) }\end{array} \\
\end{array}$ \\
\hline 1 & $\gamma-$ seliene & 0.64 & $\mathrm{C}_{15} \mathrm{H}_{24}$ & 204.35 & 10.792 \\
\hline 2 & Caryophyllene & 9.20 & $\mathrm{C}_{15} \mathrm{H}_{24}$ & 204.35 & 13.069 \\
\hline 3 & $\alpha$-trans-bergamotene & 5.06 & $\mathrm{C}_{15} \mathrm{H}_{24}$ & 204.35 & 13.488 \\
\hline 4 & Cis- $\beta$-farnesene & 16.64 & $\mathrm{C}_{15} \mathrm{H}_{24}$ & 204.35 & 14.138 \\
\hline 5 & $\gamma$-muurolene & 1.03 & $\mathrm{C}_{15} \mathrm{H}_{24}$ & 204.35 & 14.751 \\
\hline 6 & $\alpha$-curcumene & 2.29 & $\mathrm{C}_{15} \mathrm{H}_{22}$ & 202.34 & 14.951 \\
\hline 7 & $\delta$-cadinene & 2.12 & $\mathrm{C}_{15} \mathrm{H}_{24}$ & 204.35 & 16.140 \\
\hline 8 & Trans- nerolidol & 1.52 & $\mathrm{C}_{15} \mathrm{H}_{26} \mathrm{O}$ & 222.37 & 17.378 \\
\hline 9 & Cis-pinane & 21.09 & $\mathrm{C}_{10} \mathrm{H}_{18}$ & 138.25 & 24.772 \\
\hline 10 & 1,4- Eicosadiene & 2.73 & $\mathrm{C}_{20} \mathrm{H}_{38}$ & 278.82 & 25.848 \\
\hline 11 & E-phytol & 9.01 & $\mathrm{C}_{20} \mathrm{H}_{40}$ & 296.53 & 31.415 \\
\hline 12 & Phytol acetate & 7.26 & $\mathrm{C}_{22} \mathrm{H}_{42} \mathrm{O}_{2}$ & 338.32 & 33.724 \\
\hline
\end{tabular}

Table 9: GC-MS Analysis of Methanolic Extract of Aerial Parts of Conyza sumatrensis

\begin{tabular}{llllll}
\hline S/N & Compound name & $\begin{array}{c}\text { Peak } \\
\text { area } \%\end{array}$ & $\begin{array}{l}\text { Molecula } \\
\text { formula }\end{array}$ & $\begin{array}{l}\text { Molecular } \\
\text { Weight } \\
\text { g/mole }\end{array}$ & $\begin{array}{l}\text { Retention } \\
\text { time (min) }\end{array}$ \\
\hline $\mathbf{1}$ & Coumaran & 0.63 & $\mathrm{C}_{8} \mathrm{H}_{8} \mathrm{O}$ & 120.15 & 7.614 \\
$\mathbf{2}$ & 1,4-dihydroxybenzene & 1.99 & $\mathrm{C}_{6} \mathrm{H}_{6} \mathrm{O}_{2}$ & 110.11 & 9.374 \\
$\mathbf{3}$ & 2-methoxy-4-vinyl phenol & 7.96 & $\mathrm{C}_{9} \mathrm{H}_{10} \mathrm{O}_{2}$ & 150.17 & 10.066 \\
$\mathbf{4}$ & 2,6- dimethoxyl phenol & 0.92 & $\mathrm{C}_{8} \mathrm{H}_{10} \mathrm{O}_{3}$ & 154.16 & 11.148 \\
$\mathbf{5}$ & Eugenol & 8.51 & $\mathrm{C}_{10} \mathrm{H}_{12} \mathrm{O}_{2}$ & 164.2 & 11.323 \\
$\mathbf{6}$ & Caryophyllene & 3.99 & $\mathrm{C}_{15} \mathrm{H}_{24}$ & 204.35 & 13.050 \\
$\mathbf{7}$ & a-farnesene & 1.55 & $\mathrm{C}_{15} \mathrm{H}_{24}$ & 204.35 & 13.481 \\
$\mathbf{8}$ & Cis- $\beta-$ farnesene & 6.72 & $\mathrm{C}_{15} \mathrm{H}_{24}$ & 204.35 & 14.101 \\
$\mathbf{9}$ & 4- epi-cubedol & 1.18 & $\mathrm{C}_{15} \mathrm{H}_{26} \mathrm{O}$ & 222.27 & 14.958 \\
$\mathbf{1 0}$ & Nerolidyl acetate & 0.87 & $\mathrm{C}_{17} \mathrm{H}_{28} \mathrm{O}_{2}$ & 264.40 & 17.366 \\
$\mathbf{1 1}$ & (-)- spathulenol & 11.02 & $\mathrm{C}_{15} \mathrm{H}_{24} \mathrm{O}$ & 220.35 & 17.898 \\
$\mathbf{1 2}$ & Cis-pinane & 1.00 & $\mathrm{C}_{10} \mathrm{H}_{18}$ & 138.25 & 24.741 \\
$\mathbf{1 3}$ & Methyl palmitate & 13.67 & $\mathrm{C}_{17} \mathrm{H}_{35} \mathrm{O}_{2}$ & 270.45 & 26.955 \\
$\mathbf{1 4}$ & Methyl linoleate & 1.91 & $\mathrm{C}_{19} \mathrm{H}_{34} \mathrm{O}_{2}$ & 294.45 & 30.909 \\
$\mathbf{1 5}$ & Methyl linolenate & 11.69 & $\mathrm{C}_{19} \mathrm{H}_{34} \mathrm{O}_{2}$ & 292.46 & 31.071 \\
$\mathbf{1 6}$ & E-phytol & 19.36 & $\mathrm{C}_{20} \mathrm{H}_{40} \mathrm{O}$ & 296.53 & 31.403 \\
\hline
\end{tabular}

Conclusion: The aerial parts of Conyza sumatrensis have been investigated in this research and preliminary phytochemical screening of the crude extracts shows the presence of bioactive compound of medicinal uses such as tannins, glycosides, flavonoids, saponin, phenolics and terpenoids. Antimicrobial activity of crude extracts from the plant against all the test bacteria and fungi was found to be very interesting and encouraging at moderate to high concentration which justify the uses of the plant traditionally for treating chickenpox, smallpox, sore throat, ringworm and other skin related diseases. The GC-MS reveals various peaks of bioactive compounds of which the activity of the plant against 
bacteria and fungi may be attributed to the most prominent compound in synergistic effect with all the other compounds present in smaller quantities in the extract.

Acknowledgements: We are grateful to Mr Bolu Ajayi of department of Plant Biology, University of Ilorin for the identification and authentification of the plant. We are also grateful to Mr. Festus of Department of Pharmaceutical Microbiology, University of Ibadan. We also acknowledged the support of Department of Chemistry, University of Ilorin, Nigeria.

\section{REFERENCES}

Burkill HM. The useful plants on west tropical Africa. 1985; vol.3, pp 1 - 25.

Cragg, G. M.; Newman, D. J. (2001). Natural product drug discovery in the next millennium. Pharmaceut. Biol., 39 (Suppl.): 8-17

Das, K.; Tiwari, R. K. S.; Shrivastava, D. K. (2010). Techniques for evaluation of medicinal plant products as antimicrobial agent: Current methods and future trends. Journal of Medicinal Plants Research; 4(2): 104-111.

Fansworth, N. R.; Akerele, O.; Bingel, A. S.; Soejarto, D. D. (1985). Medicinal Plants in Therapy, Bull WHO, 63: 965-981

Cube, N. S.; Afolayan, A. J.; Okoh, A. I. (2008). Assessment techniques of antimicrobial properties of natural compounds of plant origin: current methods and future trends. African Journal of Biotechnology; 7 (12): 1797-1806.

Ogbeche, A. K.; Ajayi, G. O. and Onyenta, P. (1997). Antimicrobial Activities of the leaf extracts of Amgeratum conyzoids; Nig. Q. J. Hospital Med. Vol. 7 397-399

Opiyo, S. A.; Manguro, L. O. A.; Ogur, J. A. and Wagai, S. O. (2010). Bioactive Constituents of Conyza floribunda. Research Journal of Pharmacology, 4(3): 55-59. 